\title{
Knowledge management: a literature overview
}

\author{
Shana Ponelis* \\ P.O. Box 70555, Pretoria, 0041 Republic of South Africa \\ shana@ilink.nis.za
}

\begin{abstract}
Felicité A. Fairer-Wessels
Department of Information Science, University of South Africa, P.O. Box 392, Pretoria, 0003 Republic of South Africa
\end{abstract}

fairefa@alpha.unisa.ac.za

\begin{abstract}
The concept of knowledge management is becoming increasingly prevalent in academic and vocational literature. The objective of this article is to review the conceptual foundations of knowledge management starting with a conceptual clarification of knowledge relative to data and information. The characteristics in terms of forms, levels and categories of knowledge are discussed. Against this background a definition of knowledge management is sought which is compared with information management. The increasing emphasis placed on knowledge in an organisational context has given rise to a new manifestation of capital which occurs as human or structural intellectual capital. Therefore, the relation of knowledge management to corporate memory as well as the learning organisation is indicated. There are various ways in which knowledge management can be interpreted, the first being analogy; three of which occurring frequently in discussions of knowledge management (biological, economical and their convergence in bionomics) are discussed. Secondly, an indication of a paradigm shift in the approach to management is outlined and the different management styles (top-down, bottom-up and middle-up-down) are contrasted in relation to knowledge management. Finally the underlying approaches to knowledge management (people-centred versus technologycentred) are considered.
\end{abstract}

\begin{abstract}
Die konsep kennisbestuur kom toenemend voor in die akademiese sowel as populêre literatuur. Die doelstelling van hierdie artikel is om die konsepsionele gronde van kennisbestuur te ondersoek, beginnend met 'n konseptuele verheldering van kennis relatief tot inligting en data. Die kenmerkende eienskappe van kennis in terme van vorms, vlakke en kategorieë word bespreek. Gesien teen hierdie agtergrond word daar gepoog om 'n definisie van kennisbestuur te vind wat dan vergelyk word met inligtingbestuur. Die toenemende klem op kennis in organisasies het gelei tot 'n nuwe vorm van kapitaal wat voorkom as menslike of strukturele intellektuele kapitaal. Dus word die verwantskap tussen kennisbestuur en korporatiewe geheue asook die lerende organisasie bekyk. Daar is verskeie raamwerke waarbinne kennisbestuur geïnterpreteer kan word; die eerste is analogie waarvan drie wat geredelik in die literatuur voorkom (ekonomies, biologies en dié se samesmelting in sogenaamde bionomie) in verband met kennisbestuur bespreek kan word. Tweedens word 'n aanduiding gegee van 'n paradigmaverskuiwing wat kennisbestuur te weeg bring en die verskillende bestuurstyle (bo-na-onder, onder-na-bo en middel-op-af) word teenoor mekaar gestel. Laastens word die onderliggende benaderings tot kennisbestuur (mensgesentreerd versus tegnologiegesentreerd) onder die loep geneem.
\end{abstract}

Knowledge management is not a radically new concept. Horton indicated in 1979 in his evolution of resource management functions that the management of knowledge already began during the 1980s which comprised of expert systems and artificial intelligence and which recognised the economic and cultural value of knowledge (Horton 1979).

The information age has resulted in major structural changes on economic and social front and global trends have resulted in the shift towards a knowledge-based economy necessitating knowledge management. Increasing amounts of information are being generated but without the corresponding increase in the ability to manage, interpret and act on relevant information resulting in an information overload. It seems that future growth and prosperity depend on the ability to manage both information and knowledge. Although terminologically confusing, in this scenario knowledge management is proposed, mainly by business consultants, as the key to survival within this mass of knowledge and the only means to gain and maintain the competitive edge in the global economic marketplace.

\section{Problem statement}

Firstly, an attempt will be made to define or accurately describe the core concepts involved, namely data, information and knowledge as well as attempting to define knowledge management (KM) and its accompanying terminology and then to position knowledge management relative to information management. Secondly, an investigation into knowledge management as an organisational management discipline will be contemplated against a somewhat philosophical backdrop and this section is meant not to provide answers, but to inspire the reader to contemplate the effect the underlying, often philosophical-based, paradigm has on the organisation in its entirety. A limitation of this article is that it does not explicitly address the technology for 
implementing knowledge management as this aspect would warrant an article in its own right due to its extensive scope.

\section{Methodology}

The research undertaken for this article is theoretical and based on a study and synthesis of the existing literature on the topic. The scope of the literature consulted includes classic management literature, futurist articles from the eighties with predictions for the nineties and beyond, articles specifically on knowledge management, artificial intelligence, dictionaries, philosophical papers and newspaper articles.

Knowledge is an interdisciplinary field and indeed incorporates many disciplines such as philosophy (especially epistemology and ontology), economics, management (including change management), information technology, human resources, psychology, artificial intelligence, linguistics, sociology, communication studies and many more. The focus of this article will, however, be on the managerial and business aspects of knowledge management with a critical and philosophical undertone.

\section{What is knowledge management?}

\section{Definitions of data, information and knowledge}

The task of defining these three concepts in a precise way, especially knowledge and its epistomology, is a task that has received attention for many years. Lately, the question of the precise nature of data and information has been raised anew, not only in philosophy, but also in information science. There are no commonly accepted definitions of these terms, but if no working definitions of these concepts are debated there will be little progress in the discussion of these concepts especially in the field of information science. Therefore, this article will attempt to present some working definitions for discussion.

\section{According to Harris (1996:1)}

'the lowest level of known facts is data. Data has no intrinsic meaning. It must be sorted, grouped, analysed, and interpreted. When data is processed in this manner, it becomes information. Information has a substance and a purpose. However, information does not have meaning. When information is combined with context and experience, it becomes knowledge'.

Knowledge is the combination of information, context, and experience. Context is an individual's framework for viewing life. This includes influences like social values, religion, cultural heritage, and gender. Experience is previously acquired knowledge. When knowledge is transferred from one person to another, the knowledge is drawn into the receiver's context and experience (Bohm 1994; Gick \& Holyoak 1987 in Harris 1996). The new knowledge is interpreted according to the receiver's context and experience. If the receiver does not have an appropriate background for interpreting the new knowledge, the new knowledge will not be interpreted correctly and the knowledge will have little or no value. At the same time, if the sender uses a poor symbolic representation of the knowledge, the receiver will be misled or may even be unable to understand the new knowledge (Mezirow 1991 in Harris 1996). Here Harris raises the question of giving of meaning and the subjective nature of knowledge, an approach largely followed by Nonaka and Takeuchi in The knowledgecreating company (1995).

Turban and Frenzel (1992:10-11) define these concepts from a computer science and specifically an artificial intelligence perspective as follows: data refers to numeric or alphanumeric strings that by themselves do not have meaning. These can be facts or figures to be processed. Information is data organised so that it is meaningful to the person receiving it. Knowledge has several definitions: understanding, a clear and certain perception of something, learning, all that can be perceived or grasped by the mind, practical experience or skill, cognisance, recognition, organised information applicable to problem-solving.

For Taylor (1996) knowledge is formulated in the minds of individuals through experience. Knowledge is shared between groups and communities through shared experience and through the transfer of knowledge, both tacitly and explicitly. Thus the individual and community (and the organisation as a specific form of community) has a pool of knowledge. Every task or skill has specific knowledge associated with it.

Once again knowledge is highlighted as being internal to the human being and therefore subjective whereas information and data remain mostly external and objective.

Thus these concepts can be seen on a continuum where each is followed by the other and the degree of human involvement or level of added value divides the concepts. Figure 1 illustrates this idea.

Alternatively, data, information and knowledge can be classified by their degree of abstraction and by their quantity. Knowledge is the most abstract and exists in the smallest quantity. This can be represented as in Figure 2 (Turban \& Frenzel 1992:11).

The authors, however, tend to favour a semantic examination of the concepts information and knowledge. Information is the noun of the verb to inform whereas knowledge is the noun of the verb to know. Thus information is that which informs by means of a process and implies two parties, a sender and receiver (the classic communication theory) whereas knowledge is what is known and requires one party to internalise what has been received through the
Data
Information
Knowledge

LOW Level of value-added

$\mathrm{HIGH}$

Figure 1 Data, information and knowledge on a continuum based on value-added 


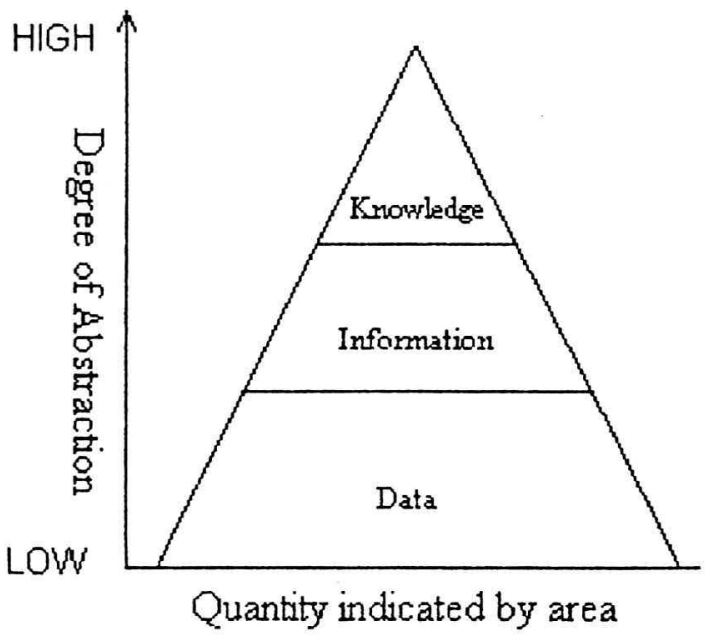

Figure 2 Knowledge, information and data based on the degree abstraction and quantity

process of informing (this process of internalisation requires giving of meaning through structuring and classification). Seen in this light, nothing can be knowledge unless it is internalised within a mind, everything outside of the mind is information which is only potential knowledge. This corresponds to Churchman's (1971:10) view that

to conceive of knowledge as a collection of information seems to rob the concept of all of its life ... Knowledge resides in the user and not in the collection. It is how the user reacts to a collection of information that matters'.

This view highlights the subjective nature of knowledge.

For the sake of thoroughness the objective nature of knowledge is also mentioned in this article. Karl Popper proposed the three world model where world $l$ is the physical world, world 2 the world of conscious experiences and thoughts and world 3 the results from world 2, in other words the contents of books, libraries and computer memories. Thus the knowledge in world 3 is the ideas from world 2 that has been objectified. Furthermore, Popper maintains that world 3 is autonomous and has an existence separate from human minds and therefore that this knowledge is not objectified but also objective (Neill 1992:7-11). This theory has largely been refuted although not falsified.

\section{Characteristics of knowledge in the business organisation}

\section{Forms of knowledge}

In 1966 the Hungarian philosopher Michael Polanyi in The tacit dimension distinguished between two forms of knowledge that can be found in an organisation, namely explicit and tacit knowledge. Explicit knowledge can be articulated in formal language and transmitted among individuals, whereas tacit knowledge is personal knowledge embedded in individual experience and involving such intangible factors as personal belief, perspective and values.

\section{Levels of knowledge}

Another distinction that can be made is the level of the knowledge: shallow or deep. Shallow knowledge refers to surface level information that can be used to deal with very specific situations for example 'if you've got a cough, try cough mixture'. It is usually a rule-of-thumb without explanation or heuristic rule. Deep knowledge on the other hand refers to the internal and causal structure of a system and considers the interactions among the system's components. Deep knowledge can be applied to different tasks and different situations. It is based on a complete, integrated body of human consciousness and includes emotions, common sense and intuition (Turban \& Frenzel 1992:120-123). This type of knowledge is extremely difficult to document, that is, make explicit. An example of deep knowledge is 'I gave the patient these pills because he had symptoms which indicate a certain condition that the pills are effective against' and even this example fails to make explicit the deep knowledge that underlies it.

Sometimes knowledge in an explicit form may appear very shallow, but this may be because its the surface manifestation of a body of very valuable deep knowledge acquired through long experience. The deep knowledge has become tacit (Taylor 1996). A classic example illustrating these characteristics of knowledge is the chess games between Gary Kasparov's and IBM's Deep Blue supercomputer. While the match was hailed as a contest between man and machine, on a more fundamental level it was a contest between individual and collective efforts. On the one hand Kasparov's knowledge was based on his individual intuition, emotions, skills, and experiences - his tacit and deep knowledge of the game. On the other hand, Deep Blue's know-how came from humanly recorded, programmed, and collectively constructed information. Its knowledge was explicit and shallow (captured in rules and cases). Chess has traditionally been one of the few success stories of machine-based reasoning since it is a closed system (definite rules, no uncertainties) and yet even here the documentation of the tacit knowledge has been unsuccessful.

It seems that tacit-deep knowledge remains problematic to transform to explicit-shallow and even more so to explicit-deep knowledge and thereby making it possible to document and store and ultimately manage.

\section{Knowledge is an abstraction}

One of the most important characteristics of knowledge is abstraction, the suppression of detail until it is needed and the exposure of the patterns of organisation of detail. The relationships, not the detail, are critical. Thus knowledge is the minimisation of information gathering and reading not increased access to information (Murray 1997a) and for this very characteristic knowledge management is seen as the nemesis to information overload. 
Furthermore, abstraction implies that knowledge does not rely on access to the original information. A symbol can be created to represent the original information and as a result knowledge can be transferred from one person to another without having to transfer all of the information.

\section{Categories of knowledge}

One reason why it is necessary to categorise knowledge is that it may be used to indicate which of the categories of knowledge is more suitable to management than others. Many different categorisations are possible. According to Willard (1997:32) the forms of knowledge directly give rise to the categories of knowledge, namely personal, embedded and recorded knowledge, which in turn is directly coupled to the area of management: people, processes or information. Therefore, information management is seen as a subdivision or specific category of knowledge management. However, in this case knowledge is not seen as internal to the human being but also seen as existing externally. Knowledge therefore has a dual nature, both objective (external) and subjective (internal).

Turban and Frenzel (1992:123) on the other hand, approach knowledge from a more subjective view. Declarative knowledge answers the 'what' question and is shallow-explicit knowledge or surface-level knowledge. Procedural knowledge answers the 'how' question. It elucidates the procedure or method that must be followed in a certain situation through step-by-step instruction. Generally it indicates how to use declarative knowledge. Semantic knowledge, on the other hand, reflects the cognitive structure of the subject and involves the use of long-term memory. Episodic knowledge is autobiographical and experimental (thus empirical) information organised by case or episode, classified by date and place and resides in longterm memory. Metaknowledge is knowledge about how to reason, how to apply knowledge and how to learn.

The knowledge mostly captured in today's knowledgebased systems is declarative and procedural knowledge and not semantic, episodic and metaknowledge, which is really the knowledge that organisations and managers aspire to capture (i.e. make explicit) in knowledge management systems. Thus the difference between a knowledge-based system and a knowledge management system would be the categories of knowledge it contains. Although a knowledge management system could contain the knowledge of the knowledge-based system the reverse would not be true as the knowledge-based system is very much the expert system of rules and cases.

\section{In search of a definition of knowledge manage- ment}

Many of the principles of knowledge management have historical roots in a variety of disciplines and thus similar ideas with different names have evolved in all these disciplines that are contributing to knowledge management.
This results in a confusion of terminology from these different contributing disciplines. Furthermore, interpretations and use of the terminology may differ according to duties and functions: managers, practitioners and technologists may have their own ideas and perspectives on what knowledge management actually is. This makes finding a clearcut definition of knowledge management a difficult task.

The most obvious definition would be application of traditional management processes to knowledge within an organisation where these management processes include planning, organisation, co-ordination and control. Seeing that the nature of knowledge defies control, this definition is trivial and almost inconsequential.

Orna (1993:161) indicates that a "high awareness of the value of information, and the intelligent use of it is necessary for an organisation to survive in the 1990s economy'.

Some other definitions found in the literature, taken from What is knowledge management? a selection of definitions from different perspectives, are:

- Policies, procedures and technologies employed for operating a continuously updated linked pair of networked databases (Anthes 1991 in What is knowledge ...)

- Bringing tacit knowledge to the surface, consolidating it in forms by which it is more widely accessible, and promoting its continuing creation (Birkett 1995 in What is knowledge ...)

- Processes of capturing, distributing, and effectively using knowledge (Davenport 1994 in What is knowledge ...)

- Creation, acquisition and transfer of knowledge and modification of organisational behavior to reflect new knowledge and insights (Garvin 1994 in What is knowledge ...)

- Identification of categories of knowledge needed to support the overall business strategy, assessment of current state of the firm's knowledge and transformation of the current knowledge base into a new and more powerful knowledge base by filling knowledge gaps (Gopal \& Gagnon 1995 in What is knowledge ...)

- Mapping knowledge and information resources both on-line and off-line; training, guiding and equipping users with knowledge access tools; monitoring outside news and information (Maglitta 1995 in What is knowledge ...)

- The management process of ensuring that the organisation's knowledge needs are met and exploiting the organisation's existing knowledge assets (Taylor 1996)

- Knowledge management involves the identification and analysis of available and required knowledge, and the subsequent planning and control of actions to develop knowledge assets so as to fulfil organisational objectives (Macintosh 1995). 
Thus it seems that knowledge management is concerned with (a) the identification of knowledge needs and assets, knowledge problems and opportunities and (b) the design, development and implementation of knowledge management strategies and solutions.

But what are these knowledge assets? Knowledge assets are mostly referred to as intellectual capital (less frequently to as corporate memory and sometimes intangible assets). According to Huang (1997) from IBM intellectual capital consists of

'information, knowledge, assets, experience, wisdom, and/or ideas that are structured to enable sharing for reuse and to deliver value to customers and shareholders'.

There are two kinds of intellectual capital: human and structural. Human intellectual capital is important as the source of innovation and renewal, but is useless if it cannot be exploited. Exploiting it requires structural intellectual capital, such as software applications, manuals and already captured know-how - to turn individual know-how into the property of the organisation (Stevenson 1995). According to Edvinsson (in Stevenson 1995), for managers and shareholders the structural intellectual capital is more important and it remains the property of the organisation and it puts new ideas to work, it amplifies the value of the human capital, and it can be used again and again to create value' (Stewart in Stevenson 1995). According to Willard's (1997: 32) categorisation of knowledge, personal knowledge residing in people can be classified as human intellectual capital and embedded and recorded knowledge as structural intellectual capital.

Intellectual capital should meet most or all of the following criteria (Huang 1997):

- Be reusable in a variety of contexts

- Be a unique, innovative concept, approach, or solution applied to a client situation

- Create or enhance a methodology or technique

- Present a comprehensive summary of information

Examples of intellectual capital may include items such as (Huang 1997):

- Trademarks, copyright and trade secrets

- Best practices, know-how and heuristic rules

- Patterns, software code, business processes and models

- Architectures, technology and business frameworks

- Project management documents (e.g. proposals, work plans, reports, meeting agendas, presentations, designs, instructional material and process maps).

In the learning organisation context knowledge management can be seen as the management of what has been learnt through organisational learning. This manifestation of knowledge through learning in an organisation is also referred to as intellectual capital. Organisational learning is the process of acquiring or collecting these intellectual assets whereas the structure wherein the learning takes place is called the learning organisation.

\section{How is knowledge management different from information management?}

As mentioned in the above section it seems that knowledge management is concerned with (a) the identification of knowledge needs and assets, knowledge problems and opportunities and (b) the design, development and implementation of knowledge management strategies and solutions which is much the same as information management with 'knowledge' substituted for 'information'.

According to Marchand and Horton (1986:124-125) knowledge management is an alternative term for strategic information management, the fifth and last stage in the evolution of the information management function.

'By this stage ... the firm has learned successfully not just how to transform data into information, but to transform information into knowledge'.

Returning to the idea mentioned earlier that the distinction between data, information and knowledge lies in the level of added value, knowledge creation is the process of adding value to information (which in turn was created by adding value to data). This process is thus an information activity and as such remains within the domain of information management, albeit as a form of progression within the field. Knowledge lies in the relationships between pieces of information and how they are organised. Knowledge management activities and information management activities can therefore be expected to correlate.

Another question raised by knowledge management is whether knowledge and its management replace information and data and its management? In the authors' opinion this is one of the pitfalls of knowledge management because knowledge can only follow on information (and therefore data) the absence of proper information and data and records management programmes and procedures will necessitate the failure of the knowledge management programme. Furthermore, knowledge management is an added dimension, intensifying the need for the integration and management of all three within an organisation.

These views are corroborated in the literature. Willard (1997:32) indicates that

'information resource management is not only consistent with information management, it has a significant part to play in the forward development of the subject'.

Skyrme (1997:26) is of the opinion that

'the techniques of information management, particularly information resource management, provide an essential foundation'.

However, there is no single answer to this question of comparison as it ultimately depends on the definition of information management and knowledge management and even more fundamentally on information and knowledge.

Furthermore, there is a gap between the academic/theoretical and the business/practical worlds. In the academic world knowledge management is a new dimension of strategic information management but in the corporate 
world, it appears to the authors that the term knowledge management is to differentiate management of content (knowledge management) with management of records (records management) and management of information technology and systems (referred to, incorrectly as far as the academic world is concerned, as information management). Therefore, it seems that knowledge management is the latest catch phrase and is hyped by business consultants as part of their marketing strategy to warrant expenditure on the part of organisations.

\section{Approaches to knowledge management}

In this section various approaches to knowledge management will be discussed. Firstly, two common analogies used in knowledge management literature will be outlined. Secondly, the most suitable management style for successful knowledge will be examined. This discussion links up with the concluding section of people-centred versus technology-centred approaches in organisations.

\section{Different analogies with regard to knowledge and organisations}

The use of inductive analogy (by means of metaphors and analogies) in thought and communication is fairly common: when one meets an unfamiliar situation which one does not understand, one tries to think of something similar to guide one in the new situation (Antonites 1996:69). Although reasoning by analogy can be extremely powerful, it is wise to recognise that it becomes dangerous when the conclusion reached by means of analogy is regarded as certain and not merely probable. Furthermore, the analogy must be appropriate for the situation (Thouless 1974:169179).

With regard to knowledge management there are two prominent analogies namely economics and biology. The economic analogy refers to accumulated knowledge as intellectual capital as an extension of the concept of capital. Although the economic analogy is generally favoured by managers due to its economic (and therefore profitable) nature it is limited somewhat as the analogy is not entirely appropriate: knowledge creation is not the same as labour and knowledge assets is not the same as other assets.

The biological analogy sees the organisation as an organism where the accumulated knowledge is referred to as a corporate memory. The idea of organisational memetics (Price 1995) builds on the biological analogy: whereas an organism is a creation of genes, an organisation can be seen as a product of the meme (or mental model) acting like a gene resulting in an organisation that self-organises around a set of unexpressed rules and assumptions. The biological analogy is also supported by the metaphor of information as lifeblood and the systems through which information is circulated is the circulatory system. Thus information enables the life of the organism (the organisation) but in itself does not initiate actions in the way knowledge resident in the brain (top management) can.

The synthesis of economic and biological theory is found in bionomics according to Taylor and Wacker (1997:100): 'the coming together of the world of the born and the world of the made'. They further predict that bionomics will flourish as an academic discipline because as a result of this merging 'economic systems will assume the properties of biological ones'.

\section{A paradigm shift?}

Before considering a paradigm shift it is necessary to examine what a paradigm is. Thomas Kuhn, an esteemed philosopher of science, noted that (Essers \& Schreinemakers 1997:25-26):

'effective research scarcely begins before a scientific community thinks it has acquired firm answers to questions like the following: What are the fundamental entities of which the universe is composed? How do these interact with each other and with the senses? What questions may legitimately be asked about such entities and what techniques employed in seeking solutions?'

The set of answers to these type of questions are referred to as a paradigm. The paradigm provides researchers and practitioners with a shared perspective on their field. In knowledge management the fundamental entity is knowledge, which has traditionally been the subject of epistemology and philosophy of science (Essers \& Schreinemakers 1997:26). Some synonyms for paradigm are conceptual framework, interpretative framework, mental model and shared vision.

Now it is possible to examine the prevailing paradigm(s). Nonaka (1991:96) notes that the managerial philosophy in the West, since F.W. Taylor and Simon, conceives the organisation as a machine for information processing (thus a paradigm founded in rationalism). The only useful knowledge is formal and systematic (thus declarative and procedural knowledge), knowledge that is or comes from hard data, formulae, codified procedures and universal principles which correspondes to the idea of eternal truths of Descartes, Spinoza, Hume and Kant (Gaarder 1996: 301). Knowledge is explicit, expressed in numbers and words and easily communicated.

On the other hand, the Eastern paradigm is based on soft and qualitative elements where knowledge is tacit and resides in the individual's experiences, beliefs and perceptions. Knowledge is acquired through learning from direct experience and trail and error. Nonaka argues for the Eastern paradigm with regard to knowledge creation and management that is intuitive and subjective (founded in empiricism). Furthermore, the organisation is seen as a living organism and flourishes in redundancy - the conscious overlapping of company information, business activities and managerial responsibilities. He stresses that management in the West must discard the notion that 
knowledge can be acquired and taught by manuals, books and lectures.

The authors are not in complete agreement with either of these paradigms of management. The synthesis arising from these paradigms will be the ideal management approach and in the literature there are quite a few authors who agree. This synthesis represents the paradigm shift that must take place in management to accommodate the subjective nature of knowledge.

Presented in this article are three paths to achieve synthesis. Firstly, Wheatley (1992) in Leadership and the new science ..., contends that we live in a world that still largely has

'Newtonian type thinking of rationality, linearity, order, hierarchy. But there are useful metaphors and images for knowledge management in organisations to be found in the "new science" of chaos theory, quantum mechanics, self-organising systems, complexity theory, non-linear systems and fractals' (Grayson 1995:10).

Thus information (not to even mention knowledge) cannot be controlled and much less managed. She proposes that information be encouraged (reminiscent of the redundancy in the Eastern approach) and let the principles of selforganising systems take over (White 1997:10).

Second is systems thinking. Senge (1990:6-7,12-13) views amongst others business and human endeavours as systems where all components are joined by interconnections and as such are "bound by the invisible fabric of interrelated actions, which often take years to fully play out their effects on each other'. But the Western paradigm focusses not on the whole system but only on parts of it, so called 'snapshots' of isolated components of the system and here lies its weakness. The adoption of systems thinking which requires a shift of mind (metanoia) will supplement this weakness. No longer are people separate from the world but connected and that 'problems are not caused by someone or something out there [but that] our own actions create the problems we experience' (square brackets are authors' own inclusion).

Lastly, information ecology, proposed by Davenport and Prusak (1997), emphasises an organisation's entire information environment. It addresses all of the organisation's values and beliefs about information - the corporate culture; how people actually use information and what they do with it (behaviour and work processes); the pitfalls that can interfere with information sharing (politics); and what information systems are already in place (technology). The 'information ecology' paradigm is holistic and multidisciplinary, relying on the

'disciplines of biology, sociology, psychology, economics, political science and business strategy and not just on engineering [information engineering] and architecture [enterprise architecture] (square brackets indicate authors' inclusion).
Information ecology has four key qualities namely (a) the integration of diverse types of information (from the biological analogy of species diversity), (b) the recognition of evolutionary change (the business environment is continuously changing and therefore the information needs as well), (c) an emphasis on observation and description instead of modelling and prescription and (d) focus on people and information behaviour (i.e. not only the providers but also the recipients).

\section{Top-down or bottom-up management style?}

According to Remeikis (1996:5) knowledge management can be "a "grass roots" sort of effort' without the involvement of senior management or their support (although she does add that top-level support is the ideal). This contrasts with Davenport's (1997a) view that assuming that knowledge management can thrive without support from senior executives is a pitfall. According to him, one might be able to build a little knowledge repository without top management support but this is unlikely to bring about any real transformations in the organisation. Grayson (1995) puts it very plainly: if knowledge management is not central to the strategy of an organisation, it is not likely 'to go anywhere'.

When surveying 25 firms that had attempted to improve knowledge work processes Davenport (1997b) found that

'in general, the most effective improvement approaches struck a middle ground between topdown re-engineering of the process and bottom-up design by autonomous knowledge workers' (authors' emphasis).

It seems that it is necessary to find the a golden midway where the best of each of these approaches are combined. Is the synthesis of these two opposing management styles to be found in the middle-up-down management process of Nonaka and Takeuchi (1995:127)? In middle-up-down management, top management gives the conceptual framework and support (Nonaka 1991) and 'encourage, recognize, and reward openness, systemic thinking, creativity' (Malhorta 1996:3). Middle-up-down management is based on teamwork where teams are largely autonomous in interpreting the strategy of top management with top management acting as a catalyst more than a leader:

'A more equivocal vision gives employees and work groups the freedom and autonomy to set their own goals. This is important because while the ideals of senior management are important, on their own they are not enough. The best that top managers can do is to clear away any obstacles and prepare the ground for self-organising groups and teams. Then it is up to the team to figure out what the ideals of the top mean in reality' (Nonaka 1991:104).

A comparison of these three approaches and their key characteristics can be seen in Table 1 which is adapted from Nonaka and Takeuchi (1995:130). 
Table $1 \mathrm{~A}$ comparison of the three management approaches and their key characteristics

\begin{tabular}{llll}
\hline & Top-down & Bottom-up & Middle-up-down \\
\hline $\begin{array}{l}\text { Agent of knowledge } \\
\text { creation }\end{array}$ & $\begin{array}{l}\text { Top } \\
\text { management }\end{array}$ & $\begin{array}{l}\text { Entrepreneurial } \\
\text { individual }\end{array}$ & Team \\
Top management role & Commander & Sponsor/mentor & Catalyst \\
Middle management & Information & Autonomous & Team \\
role & processor & intrapreneur & leader \\
Accumulated & Explicit & Tacit & Explicit and \\
knowledge & & & tacit \\
Knowledge & Computerised & Individuals & Organisational \\
storage & databases & & knowledge base \\
\hline
\end{tabular}

According to Murray there are two typical strategies in which these management approaches manifest themselves. Business managers (and knowledge management consultants who sell services to them) tend to adopt a top-down viewpoint of knowledge management. They are concerned with what managers have to know and do in order to push their organisations toward leveraging corporate intellectual assets. By contrast, technologists tend to focus on knowledge sharing and re-use, on enabling technology that can be used by all members of an organisation. They believe the right tools will make good things happen and that explicit knowledge, properly modelled, should be our primary concern. The benefits will be spread through the organisation by means of the ripple effect, often unpredictably and even chaotically.

This now leads us to consider people-centred and technology-centred approaches to management styles, specifically in relation to knowledge management, and also what the nature of knowledge is in each of these approaches (see Definitions of data, information and knowledge).

\section{People-centred or technology-centred approaches}

Following Sveiby, the first approach is the management of technology. People in this field tend to have been educated in computer science and/or information science. They are primarily involved in construction of information management systems (including organisation and retrieval of information from the system), artificial intelligence and implementing groupware solutions amongst others. Knowledge is seen as an object (supporting the objective nature of knowledge) that can be identified and handled in these systems. This approach is relatively new and is growing relatively fast due to developments in information techno$\log y$ (IT).

Secondly, there is the management of people known as human resources. People in this field probably have their education in philosophy, psychology, sociology and/or business management. They are primarily involved in assessing, changing and improving human individual skills and behaviour. To them knowledge is a process (supporting the subjective nature), a complex set of dynamic skills and know-how that is constantly changing and being adapted. This approach is relatively old, and is not growing so fast.

Each of these management foci can fall on either the individual or organisational level.

The technology-centred approach focusses on structural intellectual capital in terms of process management (embedded knowledge) and information management (recorded knowledge) whereas the people-centred approach focusses on human intellectual capital (people management).

Knowledge can not be directly managed but only indirectly through the carriers of the knowledge - the people (through human resource management) and the technology (through information management and information technology management) and the interaction between them (information flows and communication). Of the two branches in the management of knowledge (strongly coupled to the subjective versus objective nature of knowledge) the authors would side with the management of people, since people are the primary source of knowledge and technology the secondary (as storage medium of knowledge transferred from people). Placing technology first is almost certain to invite failure as (most) people resent being made to feel inferior to a machine. But although people possess the knowledge, technology is necessary for the orderly storage, retrieval, and sharing of knowledge. A balance of these two approaches is the ideal and each organisation must determine where this balance lies in their situation.

\section{Conclusion}

In 1988, Tom Peters (Orna 1993:161) identified the turbulence, unpredictability and instability of the economic climate of the $1980 \mathrm{~s}$ and predicted that the successful organisation of the 1990s and beyond will have certain characteristics, namely fewer organisational layers, more local autonomy, oriented towards differentiation, high value-added goods and services and geared towards niche markets, quality and service conscious, responsiveness, fast at innovation, utilising highly trained, flexible people as the principal means of adding value (Orna 1993:161). As has been illustrated, in principle, knowledge management

Table 2 Summary of approaches and levels of knowledge management and examples of fields that are primarily concerned with each other

\begin{tabular}{l|ll}
\hline Level & \multicolumn{2}{|c}{ Approach } \\
\hline \multirow{3}{*}{$\begin{array}{l}\text { Organisational } \\
\text { level }\end{array}$} & Knowledge = Object & Knowledge = Process \\
\cline { 2 - 3 } & Business process & $\begin{array}{l}\text { Organisational Theory } \\
\text { (Learning organisation) }\end{array}$ \\
& re-engineering (BPR) & Total Quality Management \\
Individual level & Artificial Intelligence & TQM) \\
\hline
\end{tabular}


promises to deliver most, if not all, of these characteristics to the organisation that successfully implements it. In the global market economy of today, an organisation will either have to join its competitors or eventually die (Stewart, 1991:58) and seeing that some organisations, mostly Japanese, have taken this route others will have to follow.

\section{References}

Antonites A.J. 1996. Logika en metodologie. Pretoria: UP Drukkers:69-70.

Churchman, C.W. 1971. The design of inquiring systems. New York: Basic Books.

Davenport, T. 1997a. Known evils. CIO magazine. [Online], Jun 15. Available: http://www.cio.com/CIO/061597_think.html

Davenport, T. 1997b. Some principles of knowledge management. [Online]. Available: http://www.bus.utexas.edu/kman/ kmprin.htm

Davenport, T. \& Prusak, L. 1997. Extract from The new ecology to be published by Oxford University Press in autumn 1997. [Online]. Available: http://www. infostrategy. com/vol2/no4/ ecol_pnl.htm [Online.]

Essers, J. \& Schreinemakers J. 1997. Nonaka's subjectivist conception of knowledge in corporate knowledge management. Knowledge organisation. 24(1):24-32.

Grayson, C.J. 1995. Taking inventory of your knowledge management skills. Continuous journey. [Online], Fall. Available: http://www.apqc.org/b2/b2stories/storyl.htm.

Harris, D.B. 1996, Sep. 15. Creating a knowledge centric information technology environment. [Online]. Available: http://www.htcs.com/ckc.htm.

Horton, F.W. 1979. Information resources management: concept and cases. Cleveland, Ohio: Assocation for systems management.

Huang, KT. 1997. Capitalizing collective knowledge for winning, execution and teamwork. [Online]. Available: http:// www.ibm.com/services/articles/intelcap.html.

Macintosh, A. 1995, Mar. Position paper on knowledge asset management. Artificial Intelligence Application Institute. [Online]. Available: http://www.aiai.ed.ac.uk/ alm/kam.html.

Malhotra, Y. 1996. Organizational learning and learning organizations: an overview. [Online]. Available: http:// www.brint.com/OrgLrng.htm.

Marchand, D.A. \& Horton, F.W. 1986. Infotrends: profiting from your information resources. New York: Wiley:124-125.

Murray, P.C.1997a. Information, Knowledge, and document management technology. KM Metazine. [Online], 1(2). Available: http://www.ktic.com/topic6/13_term0.htm [Online.]
Murray, P.C. 1997b. New language for new leverage: the terminology of knowledge management. KM Metazine. [Online]. Available: http://www.ktic.com/topic6/13_term0.htm.

Neill, S.D. 1992. Dilemmas in the study of information - exploring the boundaries of information science. New York: Greenwood.

Nonaka, I. 1991. The knowledge-creating company. Harvard business review, Nov.-Dec.;96-104.

Nonaka, I. \& Takeuchi, H. 1995. The knowledge-creating company: how Japanese companies create the dynamics of innovation. New York: Oxford University Press.

Orna, E. 1993. Issues and challenges for organisations in strategic use of information, in Consultancy on strategic information, edited by Z. Pejova \& F.W. Horton. Slovenia: ICPE:153-164.

Polyani, M. 1966. The tacit dimension. London: Routledge.

Price, I. 1995. Organisational memetics?: organisational learning as a selection process. Management learning, 26:299-318.

Remeikis, L. 1996. Knowledge management: the third 'era' of the information age? InfoManage, 3(10):1-5.

Senge, P.M. 1990. The fifth discipline: the art and practice of the learning organization. New York: Doubleday.

Stevenson, D.A. 1995, June. Intellectual capital \& EA. Enterprise architecture. Extract from MCom (Information Systems) [Online]. Available: http://users.iafrica.com/d/de/denniss/text/ busthem1.html.

Stewart, T.A. 1991. Brain power. Fortune magazine, June:44-60.

Sveiby, K.E. 1997. What is knowledge management? [Online]. Available: http://www2.eis.net.au/ karlerik/ Knowledge Management.html.

Taylor, J. \& Wacker, W. 1997. Speak the future. Wired 5.06. June:100-107.

Taylor, R. M. 1996. Knowledge management. [Online]. Available: http://ourworld.compuserve.com/homepages/ roberttaylor/ $\mathrm{km} \cdot \mathrm{htm}$.

Thouless, R.H. 1974. Straight and crooked thinking. London: Pan:169-179.

Turban, E. \& Frenzel, L E. 1992. Expert systems and applied artificial intelligence. New York: Macmillan.

What is knowledge management? A selection of definitions from different perspectives. 1997. [Online]. Available: http:// www.brint.com $/ \mathrm{km} / \mathrm{kmdefs.htm}$.

Wheatley, M.J. 1992. Leadership and the new science: learning about organization from an orderly universe. [S.I.]: BerretKoehler Pub.

White, T. 1997. Chains of command that block information stifle creative vision. Sunday independent business, 1 June: 10.

Willard, N. 1997. Knowledge management: what does it imply for IRM? Managing information. 4(8):31-32. 